\title{
Mechanical Stimulation (Pulsed Electromagnetic Fields "PEMF" and Extracorporeal Shock Wave Therapy "ESWT") and Tendon Regeneration: A Possible Alternative
}

\author{
Federica Rosso *, Davide E. Bonasia, Antonio Marmotti, Umberto Cottino and \\ Roberto Rossi
}

Department of Orthopaedics and Traumatology, AO Mauriziano Umberto I, Torino, Italy

The pathogenesis of tendon degeneration and tendinopathy is still partially unclear. However, an active role of metalloproteinases (MMP), growth factors, such as vascular endothelial growth factor (VEGF) and a crucial role of inflammatory elements and cytokines was demonstrated. Mechanical stimulation may play a role in regulation of inflammation. In vitro studies demonstrated that both pulsed electromagnetic fields (PEMF) and extracorporeal shock wave therapy (ESWT) increased the expression of pro-inflammatory cytokine such as interleukin (IL-6 and IL-10). Moreover, ESWT increases the expression of growth factors, such as transforming growth factor $\beta(T G F-\beta)$,

OPEN ACCESS

Edited by:

Cesare Faldini,

Istituto Ortopedico Rizzoli, Italy

Reviewed by:

Archana Mukhopadhyay,

University of Kansas, USA

Francesco Traina,

Istituto Ortopedico Rizzoli, Italy

*Correspondence:

Federica Rosso federica.rosso@yahoo.it

Received: 24 August 2015 Accepted: 26 October 2015 Published: 09 November 2015

Citation:

Rosso F, Bonasia DE, Marmotti $A$

Cottino $U$ and Rossi R (2015)

Mechanical Stimulation (Pulsed

Electromagnetic Fields "PEMF" and

Extracorporeal Shock Wave Therapy "ESWT") and Tendon Regeneration: A

Possible Alternative.

Front. Aging Neurosci. 7:211.

doi: 10.3389/fnagi.2015.00211
(VEGF), and insulin-like growth factor 1 (IGF1), as well as the synthesis of collagen I fibers.

These pre-clinical results, in association with several clinical studies, suggest a potential effectiveness of ESWT for tendinopathy treatment. Recently PEMF gained popularity as adjuvant for fracture healing and bone regeneration. Similarly to ESWT, the mechanical stimulation obtained using PEMFs may play a role for treatment of tendinopathy and for tendon regeneration, increasing in vitro TGF- $\beta$ production, as well as scleraxis and collagen I gene expression. In this manuscript the rational of mechanical stimulations and the clinical studies on the efficacy of extracorporeal shock wave (ESW) and PEMF will be discussed. However, no clear evidence of a clinical value of ESW and PEMF has been found in literature with regards to the treatment of tendinopathy in human, so further clinical trials are needed to confirm the promising hypotheses concerning the effectiveness of ESWT and PEMF mechanical stimulation.

Keywords: tendon, tendinopathy, mechanical stimulation, extracorporeal shockwaves therapy, pulsed electromagnetic fields, tendon regeneration

\section{INTRODUCTION}

Tendon disorders include both acute and chronic diseases, such as tendinopathy. It is know that the tendon tissue is poorly cellularized, with $5 \%$ of the normal tissue occupied by tenocytes that produce the extracellular matrix (ECM), based on type I collagen. Furthermore, along with tenocytes, the human tendons are also composed by tendon stem/progenitor cells (TSPCs), that guarantee to the 
tendon the ability to repair and regenerate and help in maintaining the homeostasis (Bi et al., 2007).

There is a debate on the role of inflammation in the production of degenerative changes in the tendon tissue (Abate et al., 2009; Cook and Purdam, 2009). However, recent new findings demonstrated the presence of inflammatory elements in pathologic tendons, as well as the activation of matrix metallo-proteinases, and the involvement of mediators such as substance $\mathrm{P}$, vascular endothelial growth factor (VEGF), and cyclo-oxigenase type II (COX2; De Mattei et al., 2003). Tendon healing normally occurs in three different phases: the acute inflammatory phase, for up to 3-7 days, in which the neoangiogenesis occurs, followed by the proliferative phase, for up to 21 days, when intrinsic cell proliferation of epitenon and endotenon tenocytes and extrinsic invasion of cells from the surrounding sheath and synovial occur, simultaneously with collagen, fibronectin, and elastin production, and the third remodeling phase, for up to 2 years (De Palma and Rapali, 2006; Abate et al., 2009). Different studies evaluated the molecular mechanisms that promote the healing process, such as metalloproteinases (MMPs) and MMPs with thrombospondin motifs (ADAMTs), in association with their tissue inhibitors (TIMPs; Sharma and Maffulli, 2005). Particularly MMP-9 and MMP-13 participate in collagen degradation only, while MMP-2, MMP-3, and MMP-14 are involved in both collagen degradation and remodeling (Riley et al., 2002). Indeed, different growth factors may be involved in neo-vascularization and stimulation of fibroblast and tenocytes, such as VEGF, TGF- $\beta 1$, fibroblast growth factors (FGFs), and Scleraxis (Scx; Sharma and Maffulli, 2006). Furthermore, Nitric Oxide (NO) may also be involved in the healing process (Murrell, 2007).

In this scenario, different conservative treatments were proposed to treat tendon degeneration and tendinopathy. In this manuscript, we will analyze the rationale of mechanical stimulation by Extracorporeal shock wave (ESW) and Pulsed electromagnetic fields (PEMF) for tendon regeneration, and its possible role in the treatment of different tendinopathies.

\section{EXTRACORPOREAL SHOCK WAVE THERAPY (ESWT) FOR TENDON'S PATHOLOGY}

\section{Shock Waves' Definition and Mechanism of Action}

A shock wave is a special, non-linear type of pressure wave with a short rise time (around $10 \mu \mathrm{s}$ ) and a frequency ranging from 16 to $20 \mathrm{MHz}$ (Ogden et al., 2001). These waves have a positive and negative (low-pressure) phase. In the first phase, ESW may hit an interface, with their reflection, or may gradually pass and become absorbed. The second phase causes cavitation at the tissue interfaces, with bubbles formation that subsequently implode, generating a second wave (Ogden et al., 2001). The propagating wave increase the tissue density and, as a consequence, transmit direct mechanical perturbations to the tissue with effects on cell membrane polarization, radical formation, cell proliferation, and growth factor production. Low energy ESW with a shock number ranging from 200 to 300 impulses seem most suited for enhancing cell proliferation and metabolism and, subsequently, for clinical applications.

There are two type of shockwave therapy: the focused shockwave therapy (FSWT) and the radial shockwave therapy (RSWT). Focused shockwaves are characterized by a pressure field that converges at a selected depth in the body tissues, where the maximal pressure is reached. FSWT can be generated using three methods: electro hydraulic (EH), electromagnetic (EM), and piezoelectric (PE). In all the cases the wave is generated in water, because of the acoustic impedance of water and biologic tissue are similar (van der Worp et al., 2013). The difference between the three methods of generation is the time at which the shockwave forms (Coleman and Saunders, 1989). RSWs are characterized by a diverging pressure field, which reach the maximal pressure at the source, and they are not generated in water (van der Worp et al., 2013). A recent in vitro study of Notarnicola et al. pointed out the negative effect of RWS on bone metabolism (Notarnicola et al., 2012), while some evidences in literature suggests a positive effect of RWS on the enthesis of plantar fascia and on the degenerated areas of Achilles tendon structure (van der Worp et al., 2013).

The supposed mechanism of action of ESW rely on conformational changes in membrane proteins, such as the integrins and, subsequently, on intracellular signal generation that modify gene expression and release of growth factors. Indeed, shock waves-induced repair phenomenon is observed in presence of increased level of IL-6, which is able to stimulate fibroblast production of collagen and ECM components (Waugh et al., 2015). A transient increase of IL-1b expression and a prolonged increase of IL- 8 one was also described, consistent with a modulation of initial inflammatory phase. Following these observations, it is not surprising that ESW may stimulate matrix metalloproteinase (MMP) activity. Specifically, an increased expression of MMP-2 and the pro-MMP-9 was demonstrated. Considering the well-known low level of basal repair and MMP activity (i.e., MMP-9) in degenerative tendinopathy, these concepts support the statement that ESWT may also favor tendon repair by increasing pro-MMP forms availability, allowing for greater pathological tendon remodeling by ECMdegrading enzymes and, ultimately, favoring tendon tissue regeneration. Indeed, MMPs are also capable to activate latent TGF- $\beta$ sequestered in the ECM. Nevertheless, a great interindividual variability in the response of MMP to ESW was observed. This may represent a possible biological explanation for the variations in clinical success rates of ESWT in different tendinopathies and may be a clue for recognize and identify the population of responders and non-responders to ESWT.

Vetrano et al. demonstrated that ESWT up-regulates the expression of collagen (mainly type I) and stimulate cell proliferation in primary cultured human healthy tenocytes (Vetrano et al., 2011). However, the same group compared the results of ESWT (at the dose of $0.14 \mathrm{~mJ} / \mathrm{mm}^{2}$ ) in cultured healthy and pathologic tenocytes, demonstrating that Scx and collagen type I were significantly diminished in the pathologic 
tenocytes cultures. These results indicate that the natural trigger for healing may be delayed by ESW treatment, in order to promote cellular repair (Leone et al., 2012). Pre-clinical studies showed that ESW are able to increase VEGF, VEGF receptor Flt1 , endothelial nitric oxide synthase (eNOS), and proliferating cell nuclear antigen (PCNA) expression, consistent with the initial neo-vascularization process. Improved blood supply and early vascularity is associated with the initial leukocyte infiltration and the subsequent metabolism of the fibers in the putative tendon pathological area by means of ECM-degrading enzymes (Bosch et al., 2009). This early phase is followed by an ESWdriven transitory increase in TGF- $\beta 1$ expression, later followed by persistent IGF-I expression, that leads to a controlled inhibition of macrophages-induced ECM degradation and inflammation and an enhanced ECM and collagen type I synthesis (Visco et al., 2014). Tendon cells proliferation was also associated in this repair sequence, as well as endogenous lubricin production by fibroblasts and tenocytes following growth factors stimulation (i.e., TGF- $\beta 1$; Zhang, 2011). The ultimate result of ESWT is a simulation of cell metabolism, which may induce healing process in injured areas of the tendons (Chen et al., 2004).

Recently, soft-focused ESWT was proposed, in order to deliver the energy in a larger area (Kuo et al., 2009). In the in vitro study of, de Girolamo et al. the effect of soft-focused ESWT were evaluated on a primary culture of healthy human tendon cells in adherent monolayer culture. The rationale of the study was to maintain cell-to-cell contacts and cell interactions with the ECM during ESWT, as it is a crucial point in the mechano-trasduction process. Furthermore, physical forces, such as soft-focused ESWT, may influence conformational changes in membrane proteins, such as integrines, resulting in an intracellular signal with a modification of gene expression and growth factors release (de Girolamo et al., 2014). At the molecular level, the authors evaluated the relationship between IL-1 $\beta$ and the production of MMPs, considered to be responsible for ECM degradation and tendon degeneration (Clegg et al., 2007). Both MMP-3 and 13 were not influenced by soft-focused ESW exposure, suggesting that the increased levels of IL-1 $\beta$ were not correlated with the ECM degradation. On the other hand, an increased expression of SCX, collagen type I genes (regulated by SCX expression), TGF- $\beta$, anti-inflammatory cytokines IL- 6 and Il-10 and VEGF (stimulated by IL- 6 and IL-10) was observed during the first 7 days after exposure to soft-focused ESW, although SCX transcription decreased rapidly during the first 4 days. All these results suggest that soft-focused ESWT may positively modulate the initial beneficial inflammatory phase of the tendon healing process (Visco et al., 2014) and "normalize" the anabolic activities of tendon cells.

Although the lack of sure evidence, ESWT may also be efficient in reducing calcifications in tendon structure (van der Worp et al., 2013).

\section{Clinical Results of ESWT in Tendon's Pathology Treatment}

ESWT is reported to be an effective treatment in different chronic tendon pathologies.

\section{Shoulder}

In 2014 Bannuru et al. published a systematic review on 28 Randomized Controlled Trials (RCT) comparing high-energy vs. low-energy ESWT or placebo for treatment of calcific or non-calcific tendinitis of the shoulder. The authors concluded that high-energy ESWT was significantly better than placebo in reducing pain and improving function in calcific tendinopathy, while no differences were detected between ESWT and placebo in non-calcific tendinopathy (Bannuru et al., 2014).

Huisstede et al. in 2011, in a systematic review, included 17 RCTs about ESWT vs. placebo in calcific and non-calcific rotator cuff tendinopathy. The authors concluded for strong evidence toward the best effectiveness of high-ESWT in calcific rotator cuff tendinopathy. Furthermore, no differences between the treatments were found in non-calcific rotator cuff tendinopathy (Huisstede et al., 2011). Similar results were reported in the systematic review by Harniman et al. (2004). The single studies are summarized in Table $\mathbf{1}$.

\section{Patellar Tendinopathy}

Van Leeuwen et al. in 2009 published a systematic review describing the results of ESWT in patellar tendinopathy, collecting seven RCTs on ESWT vs. placebo. The authors concluded on positive results using ESWT in treating patellar tendinopathy, but most of the studies had different frequency of treatments, application, and shockwave generation, energy level and method of localization (van Leeuwen et al., 2009). However, Zwerver et al. in 2011 published a RCT on 62 symptomatic athletes affected by patellar tendinopathy treated either with ESWT or placebo, concluding for no beneficial effects of ESWT (Zwerver et al., 2011). Due to these conflicting reports, further studies are needed to clarify the value of ESWT for patellar tendinopathy. Again, the most recent studies are summarized in Table 1.

\section{Elbow}

Buchbinder et al. in 2005 published a systematic review regarding the effectiveness and safety of ESWT for lateral elbow pain. The authors included nine trials, randomizing 1006 participants to ESWT or placebo and one trial including 93 participants randomized into ESWT or steroid injection. They concluded that steroid injections were more effective compared to ESWT (Buchbinder et al., 2005). Recently, Trentini et al. reported the results on 36 patients affected by lateral epicondylitis and treated with focal ESWT. At a mean follow-up of 24.8 months, the authors described a positive response to the treatment in $75.7 \%$ of the patients (Trentini et al., 2015). These studies outlines that, the clinical efficacy of ESWT for the treatment of medial and lateral epycondylitis is still controversial, as shown in the papers reported in Table $\mathbf{1}$.

\section{Foot Pathology}

In $2013 \mathrm{Al}$-Abbad et al. published a systematic review including six studies (4 RCTs) and evaluating the efficacy of ESWT for Achilles tendinitis treatment. The authors concluded that ESWT was effective for Achilles tendinopathy at a minimum 3 months' 
TABLE 1 | Summary of literature studies on ESWT, Extra-corporeal Shock Waves Therapy; RSWT, radial shockwave therapy.

\begin{tabular}{|c|c|c|c|c|c|c|}
\hline Authors and Year & Pathology & Number of patients & Level & Type ESWT & Follow-up & Outcomes \\
\hline \multicolumn{7}{|l|}{ SHOULDER } \\
\hline Loew et al., 1999 & $\begin{array}{l}\text { Calcific } \\
\text { tendinitis of } \\
\text { the shoulder }\end{array}$ & $\begin{array}{l}195 \text { (80 divided in } 4 \\
\text { groups with different } \\
\text { regimens, } 115 \text { divided } \\
\text { into one or two session) }\end{array}$ & $\|$ & $\begin{array}{l}\text { - High-ESWT EFD: } 0.30 \mathrm{~mJ} / \mathrm{mm}^{2} \\
\text { (high) one session-double } \\
\text { - Low-ESWT: } 0.1 \mathrm{~mJ} / \mathrm{mm}^{2} \text { (high) } \\
\text { one session-double } \\
\text { Control (no treatment; } n=20 \text { ) }\end{array}$ & Not reported & $\begin{array}{l}\text { The results showed } \\
\text { energy-dependent success. With } \\
58 \% \text { of pain relief after two } \\
\text { high-energy session }\end{array}$ \\
\hline Speed et al., 2002a & $\begin{array}{l}\text { Non-calcific } \\
\text { supraspinatus } \\
\text { tendinosis6 }\end{array}$ & 74 & $\|$ & $\begin{array}{l}\text { - ESWT: } 0.12 \mathrm{~mJ} / \mathrm{mm}^{2} \text { (medium; } \\
n=34 \text { ) } \\
\text { - ESWT: minimum: } 0.04 \mathrm{~mJ} / \mathrm{mm}^{2} \\
\text { (low; } n=40 \text { ) }\end{array}$ & Not reported & $\begin{array}{l}\text { No significant difference between the } \\
\text { treatments in terms of pain. The } \\
\text { authors concluded on no benefit of } \\
\text { ESWT in patients with non-calcific } \\
\text { tendonitis }\end{array}$ \\
\hline Haake et al., 2002 & $\begin{array}{l}\text { Calcific } \\
\text { tendinitis of } \\
\text { the } \\
\text { supraspinatus }\end{array}$ & 50 & $\|$ & $\begin{array}{l}\text { - ESWT: focus on calcific deposit: } \\
0.78 \mathrm{~mJ} / \mathrm{mm}^{2} \text { (high; } n=25 \text { ) } \\
\text { - ESWT: focused on tuberculum } \\
\text { majus: } 0.78 \mathrm{~mJ} / \mathrm{mm}^{2} \text { (high; } \\
n=25 \text { ) }\end{array}$ & 1 year & $\begin{array}{l}\text { Significantly better Constant and } \\
\text { Murley score in ESWT at the calcified } \\
\text { area under fluoroscopic control }\end{array}$ \\
\hline Pan et al., 2003 & $\begin{array}{l}\text { Calcific } \\
\text { tendinitis of } \\
\text { the shoulder }\end{array}$ & 63 & $\|$ & $\begin{array}{l}\text { - High-ES WT } 2 \mathrm{~Hz} 2000 \text { shock } \\
\text { waves, } 2 \text { sessions, } 14 \text { days apart } \\
0.26-0.32 \mathrm{~mJ} / \mathrm{mm}^{2}(n=33) \\
\text { - TENS } 3 \times / \text { week } 20 \mathrm{~min} \text { for } 4 \\
\text { weeks }(n=30)\end{array}$ & 6 months & $\begin{array}{l}\text { Better outcomes VAS and Constant } \\
\text { score in the ESWT group compared } \\
\text { to TENS group }\end{array}$ \\
\hline Peters et al., 2004 & $\begin{array}{l}\text { Calcific } \\
\text { tendinosis of } \\
\text { the shoulder }\end{array}$ & 61 & $\|$ & $\begin{array}{l}\text { - High level ESWT: } 0.44 \mathrm{~mJ} / \mathrm{mm}^{2} \\
(n=31) \\
\text { - Medium level ESWT: } \\
0.15 \mathrm{~mJ} / \mathrm{mm}^{2}(n=30)\end{array}$ & 6 months & $\begin{array}{l}\text { ESWT in calcific tendinitis of the } \\
\text { shoulder is very effective, without } \\
\text { significant side effects at } \\
0.44 \mathrm{~mJ} / \mathrm{mm}^{2}\end{array}$ \\
\hline Cosentino et al., 2004 & $\begin{array}{l}\text { Chronic } \\
\text { calcific } \\
\text { tendinitis of } \\
\text { the shoulder }\end{array}$ & 135 & IV & ESWT $0.03 \mathrm{~mJ} / \mathrm{mm}^{2}$ (4 sessions) & 1 month & $\begin{array}{l}\text { Improvement in the Constant and } \\
\text { Murley score, with partial resorption } \\
\text { of the deposits in } 44.5 \% \text { of patients, } \\
\text { and complete resorption in } 22.3 \% \text { of } \\
\text { patients }\end{array}$ \\
\hline Krasny et al., 2005 & $\begin{array}{l}\text { Calcific } \\
\text { supraspinatus } \\
\text { tendinitis }\end{array}$ & 80 & $\|$ & $\begin{array}{l}\text { - High-ESWT plus } \\
\text { Ultrasound-guided needling } \\
(n=40) \\
\text { - High-ESWT only (200 impulses } \\
\text { followed by } 2500 \text { pulses, } \\
0.36 \mathrm{~mJ} / \mathrm{mm}^{2}(n=40)\end{array}$ & $\begin{array}{l}4.1 \text { months } \\
\text { (average) }\end{array}$ & $\begin{array}{l}\text { Ultrasound-guided needling in } \\
\text { combination with high-ESWT is more } \\
\text { effective compared to ESWT alone, } \\
\text { with higher rates of deposits } \\
\text { elimination, better clinical results and } \\
\text { lower need for surgery }\end{array}$ \\
\hline
\end{tabular}




\section{TABLE 1 | Continued}

\begin{tabular}{|c|c|c|c|c|c|c|}
\hline Authors and Year & Pathology & Number of patients & Level & Type ESWT & Follow-up & Outcomes \\
\hline Cacchio et al., 2006 & $\begin{array}{l}\text { Calcific } \\
\text { tendinitis of } \\
\text { the shoulder }\end{array}$ & 50 & $\|$ & $\begin{array}{l}\text { - ESWT } 4 \text { sessions at } 1 \text {-week } \\
\text { intervals, with } 25,00 \text { pulses per } \\
\text { session, } 0.10 \mathrm{~mJ} / \mathrm{mm}^{2}(n=25) \\
\text { - ESWT } 4 \text { sessions at } 1 \text {-week } \\
\text { intervals, total number of pulses: } \\
25(n=25)\end{array}$ & 6 months & $\begin{array}{l}\text { Better functional results in the RSWT } \\
\text { group }\end{array}$ \\
\hline Albert et al., 2007 & $\begin{array}{l}\text { Calcific } \\
\text { tendinitis of } \\
\text { the shoulder }\end{array}$ & 80 & $\|$ & $\begin{array}{l}\text { - ESWT: } \max 0.45 \mathrm{~mJ} / \mathrm{mm}^{2} \text { (high; } \\
n=40 \text { ) } \\
\text { - ESWT: 0.02-0.06 mJ } / \mathrm{mm}^{2} \text { (low; } \\
n=40 \text { ) }\end{array}$ & 110 days & $\begin{array}{l}\text { High-ESWT group had significant } \\
\text { better results, but with the calcific } \\
\text { deposit unchanged in size in the } \\
\text { majority of patients }\end{array}$ \\
\hline Hsu et al., 2008 & $\begin{array}{l}\text { Calcific } \\
\text { tendinitis of } \\
\text { the shoulder }\end{array}$ & 46 & $\|$ & $\begin{array}{l}\text { - High-ESWT: } \\
0.55 \mathrm{~mJ} / \mathrm{mm}^{2}(n=33 \\
\text { - Sham ESWT }(n=13)\end{array}$ & 1 year & $\begin{array}{l}\text { No significant difference between } \\
\text { Gärtner type I and type II groups in } \\
\text { the Constant score }(P>.05) \text {. ESWT } \\
\text { are effective in the treatment of calcific } \\
\text { tendinitis with negligible complication }\end{array}$ \\
\hline Rebuzzi et al., 2008 & $\begin{array}{l}\text { Calcific } \\
\text { tendinitis of } \\
\text { the } \\
\text { supraspinatus }\end{array}$ & 46 & IV & $\begin{array}{l}\text { - Arthroscopic extirpation }(n=22) \\
\text { - Low- ESWT }(n=24)\end{array}$ & 24 months & $\begin{array}{l}\text { No differences in UCLA scores. } \\
\text { ESWT have similar results compared } \\
\text { to arthroscopy }\end{array}$ \\
\hline loppolo et al., 2012 & $\begin{array}{l}\text { Supraspinatus } \\
\text { Calcifying } \\
\text { Tendinitis }\end{array}$ & 46 & $\|$ & $\begin{array}{l}\text { - ESWT at an energy level of } \\
0.20 \mathrm{~mJ} / \mathrm{mm}^{2} \\
\text { - ESWT at an energy level of } \\
0.10 \mathrm{~mJ} / \mathrm{mm}^{2}\end{array}$ & 6 months & $\begin{array}{l}\text { Better results in the first group of } \\
\text { treatment (Constant Murley } \\
\text { Scale=CMS) }\end{array}$ \\
\hline Galasso et al., 2012 & $\begin{array}{l}\text { Non-calcifying } \\
\text { supraspinatus } \\
\text { tendinopathy }\end{array}$ & 20 & $\|$ & $\begin{array}{l}\text { - ESWT } \\
\text { - sham control group }\end{array}$ & 12 weeks & $\begin{array}{l}\text { ESWT groups showed better CMS } \\
\text { score, without any side effect }\end{array}$ \\
\hline \multicolumn{7}{|c|}{ PATELLAR TENDINOPATHY } \\
\hline Peers et al., 2003 & $\begin{array}{l}\text { Chronic } \\
\text { patellar } \\
\text { tendinopathy }\end{array}$ & 27 & III & $\begin{array}{l}\text { - Surgical treatment }(n=13) \\
\text { - ESWT }(n=14)\end{array}$ & 6 months & $\begin{array}{l}\text { ESWT showed comparable } \\
\text { outcomes compared to surgery }\end{array}$ \\
\hline Taunton and Khan, 2003 & $\begin{array}{l}\text { Chronic } \\
\text { patellar } \\
\text { tendinopathy }\end{array}$ & 30 & $\|$ & $\begin{array}{l}\text { - ESWT }(n=20) \\
\text { - ESWT with energy-absorbing } \\
\operatorname{pad}(n=10)\end{array}$ & Not reported & $\begin{array}{l}\text { ESWT is effective in adjunction with } \\
\text { eccentric exercises in treating patellar } \\
\text { tendinopathy }\end{array}$ \\
\hline Wang et al., 2007 & $\begin{array}{l}\text { Chronic } \\
\text { patellar } \\
\text { tendinopathy }\end{array}$ & 50 & $\|$ & $\begin{array}{l}\text { - ESWT }\left(0.18 \mathrm{~mJ} / \mathrm{mm}^{2} \text { energy }\right. \\
\text { flux density; } n=27) \\
\text { - Conservative treatment }(n=23)\end{array}$ & $2-3$ years & $\begin{array}{l}\text { ESWT is more effective compared to } \\
\text { conservative treatment }\end{array}$ \\
\hline
\end{tabular}


TABLE 1 | Continued

\begin{tabular}{|c|c|c|c|c|c|c|}
\hline Authors and Year & Pathology & Number of patients & Level & Type ESWT & Follow-up & Outcomes \\
\hline Vulpiani et al., 2007 & $\begin{array}{l}\text { Jumper's } \\
\text { knee }\end{array}$ & 73 & IV & $\begin{array}{l}\text { - ESWT (4 sessions 1500-2500 } \\
\text { impulses,energy varying } \\
\text { between } 0.08 \text { and } \\
0.44 \mathrm{~mJ} / \mathrm{mm}^{2} \text { ) }\end{array}$ & Not reported & $\begin{array}{l}\text { Satisfactory outcomes in ESWT } \\
\text { treatment for jumper's knee }\end{array}$ \\
\hline Zwerver et al., 2010 & $\begin{array}{l}\text { Severe } \\
\text { patellar } \\
\text { tendinopathy }\end{array}$ & 19 & IV & $\begin{array}{l}\text { Patient guided Piezo-electric, } \\
\text { focused ESWT }\end{array}$ & 3 months & $\begin{array}{l}\text { Patient guided Piezo-electric ESWT } \\
\text { without local anesthesia is a safe and } \\
\text { well-tolerated treatment for severe } \\
\text { patellar tendinopathy }\end{array}$ \\
\hline Zwerver et al., 2011 & $\begin{array}{l}\text { Patellar } \\
\text { tendinopathy } \\
\text { in athletes }\end{array}$ & 62 & I & $\begin{array}{l}\text { - ESWT }(n=31) \\
\text { - Sham ESWT }(n=31)\end{array}$ & 1 year & $\begin{array}{l}\text { No benefit of ESWT over placebo in } \\
\text { treatment of patellar tendinopathy in } \\
\text { in-season athletes }\end{array}$ \\
\hline Furia et al., 2013 & $\begin{array}{l}\text { Chronic } \\
\text { patellar } \\
\text { tendinopathy }\end{array}$ & 66 & III & $\begin{array}{l}\text { - Radial low-ESWT }(n=33) \\
\text { - Conservative treatment }(n=33)\end{array}$ & 1 year & $\begin{array}{l}\text { The percentage of "excellent" } \\
\text { functional outcomes was significantly } \\
\text { higher in the ESWT group }\end{array}$ \\
\hline \multicolumn{7}{|c|}{ ELBOW PATHOLOGY } \\
\hline Rompe et al., 2001 & $\begin{array}{l}\text { Chronic } \\
\text { lateral } \\
\text { epicondylitis } \\
\text { of the elbow }\end{array}$ & 30 & $\|$ & $\begin{array}{l}\text { - ESWT }\left(0.16 \mathrm{~mJ} / \mathrm{mm}^{2}\right) \\
\text { - ESWT }\left(0.16 \mathrm{~mJ} / \mathrm{mm}^{2}\right) \text { plus } \\
\text { cervical manual therapy }\end{array}$ & 1 year & $\begin{array}{l}\text { Each group showed significant } \\
\text { improvement in the pain and } \\
\text { functional scores. The authors } \\
\text { concluded that ESWT may be an } \\
\text { effective conservative treatment } \\
\text { method for unilateral chronic tennis } \\
\text { elbow }\end{array}$ \\
\hline Maier et al., 2001 & $\begin{array}{l}\text { Chronic } \\
\text { lateral tennis } \\
\text { elbow }\end{array}$ & 42 & IV & ESWT & 18.6 months & $\begin{array}{l}\text { Good clinical performances after } \\
\text { ESWT. Male patients performed } \\
\text { better than female ones. In female } \\
\text { patients, Magnetic Resonance } \\
\text { Imaging (MRI) may predict the results } \\
\text { of ESWT }\end{array}$ \\
\hline Speed et al., 2002b & $\begin{array}{l}\text { Lateral } \\
\text { epicondylitis }\end{array}$ & 75 & $\|$ & $\begin{array}{l}\text { - ESWT at } 0.12 \mathrm{~mJ} / \mathrm{mm}^{2} \\
\text { - Sham therapy }\end{array}$ & 1 year & $\begin{array}{l}\text { No significant difference between the } \\
\text { groups, concluding that the placebo } \\
\text { effect of ESWT may be considerable }\end{array}$ \\
\hline Melegati et al., 2004 & $\begin{array}{l}\text { Lateral } \\
\text { epicondylitis }\end{array}$ & 41 & $\|$ & $\begin{array}{l}\text { - ESWT (Lateral tangential } \\
\text { focusing) } \\
\text { - ESWT (tangential focusing) }\end{array}$ & Not reported & $\begin{array}{l}\text { No differences between the } \\
\text { techniques }\end{array}$ \\
\hline Furia, 2005 & $\begin{array}{l}\text { Chronic } \\
\text { lateral } \\
\text { epicondylitis }\end{array}$ & 36 & IV & ESWT & Not reported & $\begin{array}{l}77.8 \% \text { were rated excellent or good } \\
\text { on the Roles and Maudsley scale }\end{array}$ \\
\hline Chung et al., 2005 & $\begin{array}{l}\text { Chronic } \\
\text { lateral } \\
\text { epicondylitis }\end{array}$ & 60 & $\|$ & $\begin{array}{l}\text { - ESWT + stretching program } \\
\text { - Sham therapy }\end{array}$ & 1 year & No differences in clinical outcomes \\
\hline Staples et al., 2008 & $\begin{array}{l}\text { Lateral } \\
\text { epicondylitis }\end{array}$ & 68 & $\|$ & $\begin{array}{l}\text { - } 3 \text { ESWT treatments } \\
\text { - } 3 \text { treatments at a subtherapeutic } \\
\text { dose }\end{array}$ & 6 months & $\begin{array}{l}\text { Little evidence in favor of ESWT in the } \\
\text { treatment of lateral epicondylitis }\end{array}$ \\
\hline Radwan et al., 2008 & $\begin{array}{l}\text { Resistant } \\
\text { tennis elbow }\end{array}$ & 46 & $\|$ & $\begin{array}{l}\text { - high- ESWT (0.22 mJ/mm²; } \\
n=29) \\
\text { - Percutanous tenotomy }(n=27)\end{array}$ & 1 year & $\begin{array}{l}\text { Excellent and good results were } \\
\text { achieved in } 65.5 \% \text { of patients in } \\
\text { ESWT group and } 74.1 \% \text { in the } \\
\text { percutanous group }\end{array}$ \\
\hline Gunduz et al., 2012 & $\begin{array}{l}\text { Lateral } \\
\text { epicondylitis }\end{array}$ & 59 & $\|$ & $\begin{array}{l}\text { - Physical therapy } \\
\text { - A single corticosteroid injection } \\
\text { - ESWT }\end{array}$ & 6 months & $\begin{array}{l}\text { All the treatment had favorable effects } \\
\text { on pain and grip strength in the early } \\
\text { period }\end{array}$ \\
\hline
\end{tabular}


TABLE 1 | Continued

\begin{tabular}{|c|c|c|c|c|c|c|}
\hline Authors and Year & Pathology & Number of patients & Level & Type ESWT & Follow-up & Outcomes \\
\hline Lee et al., 2012 & $\begin{array}{l}\text { Medial and } \\
\text { lateral } \\
\text { epicondylitis }\end{array}$ & 22 & III & $\begin{array}{l}\text { - ESWT group } \\
\left(0.06-0.12 \mathrm{~mJ} / \mathrm{mm}^{2} ; n=12\right) \\
\text { - local steroid injection group } \\
(n=10)\end{array}$ & 8 weeks & $\begin{array}{l}\text { Both the treatments were effective for } \\
\text { medial and lateral epicondylitis }\end{array}$ \\
\hline Notarnicola et al., 2014 & Epicondylitis & 26 & IV & ESWT & Not reported & $\begin{array}{l}\text { Progressive improvement in pain } \\
\text { during the follow-up, with decrease in } \\
\text { grip strength, especially in the } \\
\text { dominant limb }\end{array}$ \\
\hline Trentini et al., 2015 & $\begin{array}{l}\text { Lateral } \\
\text { epicondylitis }\end{array}$ & 36 & IV & Focused ESWT & 24.8 months & $\begin{array}{l}75.7 \% \text { of positive response. Focal } \\
\text { ESWT is a valuable and safe solution } \\
\text { in case of lateral epicondylitis, both in } \\
\text { newly diagnosed and previously } \\
\text { treated cases }\end{array}$ \\
\hline \multicolumn{7}{|l|}{ FOOT PATHOLOGY } \\
\hline Furia, 2006 & $\begin{array}{l}\text { Insertional } \\
\text { Achilles } \\
\text { tendinopathy }\end{array}$ & 88 & $\|$ & $\begin{array}{l}\text { - ESWT group; } 0.21 \mathrm{~mJ} / \mathrm{mm}^{2} \\
\text { total energy flux density, } \\
604 \mathrm{~mJ} / \mathrm{mm}^{2}(n=35) \\
\text { - Non-operative therapy }(n=33)\end{array}$ & 1 year & $\begin{array}{l}\text { Better Roles and Maudsley results in } \\
\text { the ESWT group. NO differences if a } \\
\text { local anesthesia was performed or } \\
\text { not before the ESWT session }\end{array}$ \\
\hline Rasmussen et al., 2008 & $\begin{array}{l}\text { Chronic } \\
\text { Achilles } \\
\text { tendinopathy }\end{array}$ & 48 & $\|$ & $\begin{array}{l}\text { - active ESWT } \\
\text { - sham ESWT }\end{array}$ & 12 weeks & $\begin{array}{l}\text { Better results in the active ESWT } \\
\text { group }\end{array}$ \\
\hline Vulpiani et al., 2009 & $\begin{array}{l}\text { Achilles } \\
\text { tendinopathy }\end{array}$ & 115 & IV & ESWT (0.08 and $\left.0.40 \mathrm{~mJ} / \mathrm{mm}^{2}\right)$ & 1 year & $\begin{array}{l}76 \% \text { of satisfactory results at the last } \\
\text { follow-up }\end{array}$ \\
\hline Saxena et al., 2011 & $\begin{array}{l}\text { Achilles } \\
\text { tendinopathy }\end{array}$ & 74 & IV & ESWT & 1 year & $\begin{array}{l}74.8 \% \text { of patients improved } 1 \text { year } \\
\text { after surgery, with significant } \\
\text { improvement of the Roles and } \\
\text { Maudsley score }\end{array}$ \\
\hline Kim et al., 2015 & $\begin{array}{l}\text { Plantar } \\
\text { fasciitis }\end{array}$ & 10 & IV & ESWT & 6 months & $\begin{array}{l}\text { Decreased plantar fascia thickness, } \\
\text { spasticity, and pain and increased } \\
\text { gait ability after ESWT }\end{array}$ \\
\hline
\end{tabular}

follow-up (Al-Abbad and Simon, 2013). Other studies pointed out similar conclusions as shown in Table $\mathbf{1 .}$

Recently, Kim et al. analyzed the efficacy of ESWT also for plantar fasciitis in stroke patients, reporting on reduced tension in the plantar fascia, and observing pain relief and improved gait ability (Kim et al., 2015; Table 1). Their results are similar to other recent studies (Park et al., 2014; Yin et al., 2014; Gollwitzer et al., 2015; Konjen et al., 2015; Mardani-Kivi et al., 2015), and allows for considering ESW a precious therapeutic modality for treating acute or recalcitrant plantar fasciitis with acceptable success rate ranging from $50 \%$ to $80 \%$, at least at a short term follow-up.

\section{PULSED ELECTROMAGNETIC FIELDS (PEMF) FOR TENDON'S PATHOLOGY}

\section{Pulsed Electromagnetic Fields (PEMF) Definition and Mechanism of Action}

PEMF are characterized by frequencies at the low end of the electromagnetic spectrum, ranging between 6 and $500 \mathrm{~Hz}$
(Bassett, 1989). Another feature of PEMF waveforms is the rate of change: higher rate of changes (Tesla/seconds) are able to induce biological currents in the tissue, with peculiar biological effects (Juutilainen and Lang, 1997). Furthermore, it was demonstrated that low-frequency fields are non-ionizing and athermal (Rubik, 1997).

Different types of waveforms were associated to PEMF: asymmetric, biphasic, sinusoidal, quasi-rectangular, or quasitriangular in shape (Bassett, 1989). In 1979, the Food and Drug Administration (FDA) approved both quasi-rectangular and quasi-triangular PEMF as safe and effective for the treatment of fractures and their sequelae (Bassett, 1989).

There are two methods in which PEMF can be applied to biological tissues: capacitive or inductive coupling. Capacitive coupling does not involve any contact with the body. However, in direct capacitive coupling, an electrode has to be placed on the skin of the opposite side (Trock, 2000). On contrary inductive coupling does not require the electrodes to be in direct contact with the skin, because the magnetic field produces an electric field that, in turn, produces a current in the conductive tissues of the body (Stiller et al., 1992; Trock, 2000). 
Similarly to ESW, PEMF are physical stimuli that produce membrane disturbances and activation of multiple intracellular pathways. Indeed, formation of lipidic "nanopores" in the plasma membrane following PEMF exposure may explain the conduction of ions into the cell from the extracellular space, specifically Calcium ions (Ca). Furthermore, a direct effect of PEMF on phospholipids within the plasma membrane has been postulated, with a subsequent production of several second messengers, initiating multiple intracellular signal transduction pathways, as well as a further activation of protein kinase $\mathrm{C}$ (Semenov et al., 2013; Tolstykh et al., 2013).

Nevertheless, PEMFs have been recently connected to other cell activation pathways. In particular, the ligand-independent activation of epidermal growth factor receptor (EGFR) and other members of the receptor tyrosine kinase family were observed, with subsequent stimulation of intracellular signaling as the MAPK (mitogen-activated protein kinases)/ERK (extracellular signal-regulated kinases) pathway, with subsequently activation of intracellular mitogenic pathway (Wolf-Goldberg et al., 2013).

Recent studies outlined the expression of canonical Wnt signaling proteins (Wnt1/ lipoprotein receptor-related protein 5 LRP5/beta-catenin) in cell derived from a mesenchymal lineage and exposed to PEMF (Jing et al., 2013; Zhou et al., 2015). At this regard, the presence of beta-catenin seems particularly important with respect to other settings, in which this protein is linked to cell plasticity and proliferation, as in the superficial zone of articular cartilage (Yasuhara et al., 2011; Marmotti et al., 2013).

Finally, the exposure to PEMF induces early up-regulation of adenosine receptor $A_{2 A}$ and $A_{3}$. Adenosine receptor $A_{2 A}$ and $A_{3}$ are able to reduce PGE2 and pro-inflammatory cytokine IL- 6 and IL-8 release and to inhibit the activation of transcription factor $\mathrm{NF}-\mathrm{kB}$, a key regulator of inflammatory responses (Vincenzi et al., 2013), as well as to positively interfere in several cell activities as cell proliferation (Varani et al., 2008).

Taken together, all these observations suggest a possible role of PEMF for "tenocyte activation" (Dingemanse et al., 2014; de Girolamo et al., 2015). This may be achieved by two main mechanisms: (i) limiting the catabolic effects of pro-inflammatory cytokines such as IL-1, IL-6, and IL-8 and (ii) increasing ECM production, cytokine release and cell proliferation (De Mattei et al., 2003; Fassina et al., 2006; Ongaro et al., 2012; de Girolamo et al., 2013). Recent studies of de Girolamo et al. (de Girolamo et al., 2013, 2015) demonstrated that human tendon cells proliferation was enhanced after PEMF treatment, and in particular, that a $1.5 \mathrm{mT}$-PEMF treatment was able to up-regulate SCX, VEGF-A, and COL1A1 gene expression. Moreover, the treated tendon cells showed, after 2 days, a higher release of IL-6, IL-10, and TGF- $\beta$. These effects are essential for tendon metabolism, inducing increased elastin and fibronectin production, increased cell proliferation and neo-angiogenesis.

\section{Clinical Results of PEMF in Tendon's Pathology Treatment}

Despite the lack of recent literature sustaining a long-term positive effect of PEMF in treating shoulder and elbow tendon disorders (Uzunca et al., 2007; Bisset et al., 2011; Dingemanse et al., 2014), a positive effect of PEMF in reducing lateral epicondylitis pain was described at a short term follow-up (3 months). Moreover, several reports back in the 80 's proposed a putative role in the treatment of rotator cuff disease and lateral epicondylitis (Binder et al., 1984; Devereaux et al., 1985). A very recent study by Osti et al. described a possible role of PEMF after rotator cuff repair as an adjuvant treatment, in order to reduce local inflammation, post-operative joint swelling and stiffness, and recovery time, as well as to induce pain relief. A significant short term (up to 5 months) positive effect was observed in PEMF treated patients, but the authors did not observe any clinical and functional improvement at a longer (2 years) follow-up (Osti et al., 2015).

Some suggestions for the use of PEMF for treating human Achilles tendon pathologies come only from preclinical animal studies. Strauch et al. in 2006 analyzed the effect of PEMF on the biomechanical strength of rat Achilles' tendons at 3 weeks after transection and surgical repair, with an increase in tensile strength of up to $69 \% 3$ weeks after the surgery (Strauch et al., 2006). Previously, Lee et al. in 1997 analyzed the possible role of pulsed magnetic fields (PMF) and (PEMF) in the healing process of Achilles tendon inflammation in the rat (Lee et al., 1997).

\section{CONCLUSION}

Mechanical stimulation by means of ESW and PEMF seems to be favorable for tendon regeneration in preclinical and in vitro studies. Indeed, a beneficial effect has been demonstrated on tendon resident cells at a cellular level. Increased cell proliferation and the production of the immuno-regulatory cytokines and growth and angiogenic factors was observed in vitro, consistent with an overall "tenocyte activation" favoring tendon healing process. Conversely, there is still a lack of strong evidences on ESW and PEMF when dealing with clinical settings. The efficacy of ESWT is demonstrated for the treatment of calcific rotator cuff tendinopathy, while it is still debated its role in the treatment of other tendon disorders, such as patellar tendinopathy and lateral epicondylitis. PEMF seem to exert positive clinical effects toward shoulder and elbow tendon disorders only at a short term follow up. While basic science research continues to show encouraging results, further in vivo human studies are undoubtedly necessary to confirm the clinical efficacy of mechanical stimulation by means of PEMF and ESW for the treatment of tendon disorders.

\section{AUTHOR CONTRIBUTIONS}

FR Substantial contributions to the conception or design of the work, drafting the work, acquisition, analysis, or interpretation of data for the work. DB Substantial contributions to the conception or design of the work, revising the work. AM Substantial contributions to the conception or design of the work, revising the work. UC Substantial contributions to the conception or design of the work, revising the work. RR Revising the work, Final approval of the version to be published.

\section{ACKNOWLEDGMENTS}

The work was produced at the AO Mauriziano Umberto I, Largo Turati 62, 10128, Torino, Italy 


\section{REFERENCES}

Abate, M., Silbernagel, K. G., Siljeholm, C., Di Iorio, A., De Amicis, D., Salini, V., et al. (2009). Pathogenesis of tendinopathies: inflammation or degeneration? Arthritis Res. Ther. 11, 235. doi: 10.1186/ar2723

Al-Abbad, H., and Simon, J. V. (2013). The effectiveness of extracorporeal shock wave therapy on chronic achilles tendinopathy: a systematic review. Foot Ankle Int. 34, 33-41. doi: 10.1177/1071100712464354

Albert, J. D., Meadeb, J., Guggenbuhl, P., Marin, F., Benkalfate, T., Thomazeau, H., et al. (2007). High-energy extracorporeal shock-wave therapy for calcifying tendinitis of the rotator cuff: a randomised trial. J. Bone Joint Surg. Br. Vol. 89, 335-341. doi: 10.1302/0301-620X.89B3.18249

Bannuru, R. R., Flavin, N. E., Vaysbrot, E., Harvey, W., and McAlindon, T. (2014). High-energy extracorporeal shock-wave therapy for treating chronic calcific tendinitis of the shoulder: a systematic review. Ann. Intern. Med. 160, 542-549. doi: $10.7326 /$ M13-1982

Bassett, C. A. (1989). Fundamental and practical aspects of therapeutic uses of pulsed electromagnetic fields (PEMFs). Crit. Rev. Biomed. Eng. 17, 451-529.

Bi, Y., Ehirchiou, D., Kilts, T. M., Inkson, C. A., Embree, M. C., Sonoyama, W., et al. (2007). Identification of tendon stem/progenitor cells and the role of the extracellular matrix in their niche. Nat. Med. 13, 1219-1227. doi: $10.1038 / \mathrm{nm} 1630$

Binder, A., Parr, G., Hazleman, B., and Fitton-Jackson, S. (1984). Pulsed electromagnetic field therapy of persistent rotator cuff tendinitis. A double-blind controlled assessment. Lancet 1, 695-698. doi: 10.1016/S01406736(84)92219-0

Bisset, L., Coombes, B., and Vicenzino, B. (2011). Tennis elbow. BMJ Clin. Evid. 2011:1117.

Bosch, G., de Mos, M., van Binsbergen, R., van Schie, H. T., van de Lest, C. H., and van Weeren, P. R. (2009). The effect of focused extracorporeal shock wave therapy on collagen matrix and gene expression in normal tendons and ligaments. Equine Vet. J. 41, 335-341. doi: 10.2746/042516409X370766

Buchbinder, R., Green, S. E., Youd, J. M., Assendelft, W. J., Barnsley, L., and Smidt, N. (2005). Shock wave therapy for lateral elbow pain. Cochrane Database Syst. Rev. CD003524. doi: 10.1002/14651858.cd003524.pub2

Cacchio, A., Paoloni, M., Barile, A., Don, R., de Paulis, F., Calvisi, V., et al. (2006). Effectiveness of radial shock-wave therapy for calcific tendinitis of the shoulder: single-blind, randomized clinical study. Phys. Ther. 86, 672-682.

Chen, Y. J., Wang, C. J., Yang, K. D., Kuo, Y. R., Huang, H. C., Huang, Y. T., et al. (2004). Extracorporeal shock waves promote healing of collagenase-induced Achilles tendinitis and increase TGF-betal and IGF-I expression. J. Orthop. Res. 22, 854-861. doi: 10.1016/j.orthres.2003.10.013

Chung, B., Wiley, J. P., and Rose, M. S. (2005). Long-term effectiveness of extracorporeal shockwave therapy in the treatment of previously untreated lateral epicondylitis. Clin. J. Sport Med. 15, 305-312.

Clegg, P. D., Strassburg, S., and Smith, R. K. (2007). Cell phenotypic variation in normal and damaged tendons. Int. J. Exp. Pathol. 88, 227-235. doi: 10.1111/j.1365-2613.2007.00549.x

Coleman, A. J., and Saunders, J. E. (1989). A survey of the acoustic output of commercial extracorporeal shock wave lithotripters. Ultrasound Med. Biol. 15, 213-227. doi: 10.1016/0301-5629(89)90066-5

Cook, J. L., and Purdam, C. R. (2009). Is tendon pathology a continuum? A pathology model to explain the clinical presentation of load-induced tendinopathy. Br. J. Sports Med. 43, 409-416. doi: 10.1136/bjsm.2008.051193

Cosentino, R., Selvi, E., De Stefano, R., Frati, E., Manca, S., Hammoud, M., et al. (2004). Extracorporeal shock wave therapy for chronic calcific tendinitis of the shoulder. Clin. Rheumatol. 23, 475-477. doi: 10.1007/s10067-004-0883-x

de Girolamo, L., Stanco, D., Galliera, E., Viganò, M., Colombini, A., Setti, S., et al. (2013). Low frequency pulsed electromagnetic field affects proliferation, tissuespecific gene expression, and cytokines release of human tendon cells. Cell Biochem. Biophys. 66, 697-708. doi: 10.1007/s12013-013-9514-y

de Girolamo, L., Stanco, D., Galliera, E., Viganò, M., Lovati, A. B., Marazzi, M. G., et al. (2014). Soft-focused extracorporeal shock waves increase the expression of tendon-specific markers and the release of anti-inflammatory cytokines in an adherent culture model of primary human tendon cells. Ultrasound Med. Biol. 40, 1204-1215. doi: 10.1016/j.ultrasmedbio.2013.12.003

de Girolamo, L., Viganò, M., Galliera, E., Stanco, D., Setti, S., Marazzi, M. G., et al. (2015). In vitro functional response of human tendon cells to different dosages of low-frequency pulsed electromagnetic field. Knee Surg. Sports Traumatol. Arthrosc. 23, 3443-3453. doi: 10.1007/s00167-014-3143-x

De Mattei, M., Pasello, M., Pellati, A., Stabellini, G., Massari, L., Gemmati, D., et al. (2003). Effects of electromagnetic fields on proteoglycan metabolism of bovine articular cartilage explants. Connect. Tissue Res. 44, 154-159. doi: $10.1080 / 03008200390208546$

De Palma, L. G. A., and Rapali, S. (2006). Physiopathology of the repair process of lesions of Achilles tendon. Foot Ankle Surg. 12, 5-11. doi: 10.1016/j.fas.2005.08.005

Devereaux, M. D., Hazleman, B. L., and Thomas, P. P. (1985). Chronic lateral humeral epicondylitis-a double-blind controlled assessment of pulsed electromagnetic field therapy. Clin. Exp. Rheumatol. 3, 333-336.

Dingemanse, R., Randsdorp, M., Koes, B. W., and Huisstede, B. M. (2014). Evidence for the effectiveness of electrophysical modalities for treatment of medial and lateral epicondylitis: a systematic review. Br. J. Sports Med. 48, 957-965. doi: 10.1136/bjsports-2012-091513

Fassina, L., Visai, L., Benazzo, F., Benedetti, L., Calligaro, A., De Angelis, M. G., et al. (2006). Effects of electromagnetic stimulation on calcified matrix production by SAOS-2 cells over a polyurethane porous scaffold. Tissue Eng. 12, 1985-1999. doi: 10.1089/ten.2006.12.1985

Furia, J. P. (2005). Safety and efficacy of extracorporeal shock wave therapy for chronic lateral epicondylitis. Am. J. Orthop. 34, 13-19. discussion: 19.

Furia, J. P. (2006). High-energy extracorporeal shock wave therapy as a treatment for insertional Achilles tendinopathy. Am. J. Sports Med. 34, 733-740. doi: $10.1177 / 0363546505281810$

Furia, J. P., Rompe, J. D., Cacchio, A., Del Buono, A., and Maffulli, N. (2013). A single application of low-energy radial extracorporeal shock wave therapy is effective for the management of chronic patellar tendinopathy. Knee Surg. Sports Traumatol. Arthrosc. 21, 346-350. doi: 10.1007/s00167-012-2057-8

Galasso, O., Amelio, E., Riccelli, D. A., and Gasparini, G. (2012). Short-term outcomes of extracorporeal shock wave therapy for the treatment of chronic non-calcific tendinopathy of the supraspinatus: a double-blind, randomized, placebo-controlled trial. BMC Musculoskelet. Disord. 13:86. doi: 10.1186/14712474-13-86

Gerdesmeyer, L., Wagenpfeil, S., Haake, M., Maier, M., Loew, M., Wörtler, K., et al. (2003). Extracorporeal shock wave therapy for the treatment of chronic calcifying tendonitis of the rotator cuff: a randomized controlled trial. JAMA 290, 2573-2580. doi: 10.1001/jama.290.19.2573

Gollwitzer, H., Saxena, A., DiDomenico, L. A., Galli, L., Bouche, R. T., Caminear, D. S., et al. (2015). Clinically relevant effectiveness of focused extracorporeal shock wave therapy in the treatment of chronic plantar fasciitis: a randomized, controlled multicenter study. J. Bone Joint Surg. Am. 97, 701-708. doi: 10.2106/JBJS.M.01331

Gunduz, R., Malas, F. U., Borman, P., Kocaoglu, S., and Ozcakar, L. (2012). Physical therapy, corticosteroid injection, and extracorporeal shock wave treatment in lateral epicondylitis. Clinical and ultrasonographical comparison. Clin. Rheumatol. 31, 807-812. doi: 10.1007/s10067-012-1939-y

Haake, M., Deike, B., Thon, A., and Schmitt, J. (2002). Exact focusing of extracorporeal shock wave therapy for calcifying tendinopathy. Clin. Orthop. Relat. Res. 397, 323-331. doi: 10.1097/00003086-200204000-00037

Harniman, E., Carette, S., Kennedy, C., and Beaton, D. (2004). Extracorporeal shock wave therapy for calcific and noncalcific tendonitis of the rotator cuff: a systematic review. J. Hand Ther. 17, 132-151. doi: 10.1197/j.jht.2004.02.003

Hsu, C. J., Wang, D. Y., Tseng, K. F., Fong, Y. C., Hsu, H. C., and Jim, Y. F. (2008). Extracorporeal shock wave therapy for calcifying tendinitis of the shoulder. J. Shoulder Elbow Surg. 17, 55-59. doi: 10.1016/j.jse.2007.03.023

Huisstede, B. M., Gebremariam, L., van der Sande, R., Hay, E. M., and Koes, B. W. (2011). Evidence for effectiveness of Extracorporal Shock-Wave Therapy (ESWT) to treat calcific and non-calcific rotator cuff tendinosis-a systematic review. Man. Ther. 16, 419-433. doi: 10.1016/j.math.2011.02.005

Ioppolo, F., Tattoli, M., Di Sante, L., Attanasi, C., Venditto, T., Servidio, M., et al. (2012). Extracorporeal shock-wave therapy for supraspinatus calcifying tendinitis: a randomized clinical trial comparing two different energy levels. Phys. Ther. 92, 1376-1385. doi: 10.2522/ptj.20110252

Jing, D., Li, F., Jiang, M., Cai, J., Wu, Y., Xie, K., et al. (2013). Pulsed electromagnetic fields improve bone microstructure and strength in ovariectomized rats through a Wnt/Lrp5/beta-catenin signaling-associated mechanism. PLoS ONE 8:e79377. doi: 10.1371/journal.pone.0079377 
Juutilainen, J., and Lang, S. (1997). Genotoxic, carcinogenic and teratogenic effects of electromagnetic fields. Introduction and overview. Mutat. Res. 387, 165-171. doi: 10.1016/S1383-5742(97)00036-7

Kim, T. G., Bae, S. H., Kim, G. Y., and Kim, K. Y. (2015). The effects of extracorporeal shock wave therapy on stroke patients with plantar fasciitis. J. Phys. Ther. Sci. 27, 523-526. doi: 10.1589/jpts.27.523

Konjen, N., Napnark, T., and Janchai, S. (2015). A comparison of the effectiveness of radial extracorporeal shock wave therapy and ultrasound therapy in the treatment of chronic plantar fasciitis: a randomized controlled trial. J. Med. Assoc. Thai. 98(Suppl. 1), S49-S56.

Krasny, C., Enenkel, M., Aigner, N., Wlk, M., and Landsiedl, F. (2005). Ultrasoundguided needling combined with shock-wave therapy for the treatment of calcifying tendonitis of the shoulder. J. Bone Joint Surg. Br. 87, 501-507. doi: 10.1302/0301-620X.87B4.15769

Kuo, Y. R., Wang, C. T., Wang, F. S., Chiang, Y. C., and Wang, C. J. (2009). Extracorporeal shock-wave therapy enhanced wound healing via increasing topical blood perfusion and tissue regeneration in a rat model of STZinduced diabetes. Wound Repair Regen. 17, 522-530. doi: 10.1111/j.1524475X.2009.00504.X

Lee, E. W., Maffulli, N., Li, C. K., and Chan, K. M. (1997). Pulsed magnetic and electromagnetic fields in experimental achilles tendonitis in the rat: a prospective randomized study. Arch. Phys. Med. Rehabil. 78, 399-404. doi: 10.1016/S0003-9993(97)90232-X

Lee, S. S., Kang, S., Park, N. K., Lee, C. W., Song, H. S., Sohn, M. K., et al. (2012). Effectiveness of initial extracorporeal shock wave therapy on the newly diagnosed lateral or medial epicondylitis. Ann. Rehabil. Med. 36, 681-687. doi: 10.5535/arm.2012.36.5.681

Leone, L., Vetrano, M., Ranieri, D., Raffa, S., Vulpiani, M. C., Ferretti, A., et al. (2012). Extracorporeal Shock Wave Treatment (ESWT) improves in vitro functional activities of ruptured human tendon-derived tenocytes. PLOS ONE 7:e49759. doi: 10.1371/journal.pone.0049759

Loew, M., Daecke, W., Kusnierczak, D., Rahmanzadeh, M., and Ewerbeck, V. (1999). Shock-wave therapy is effective for chronic calcifying tendinitis of the shoulder. J. Bone Joint Surg. Br. 81, 863-867. doi: 10.1302/0301620X.81B5.9374

Maier, M., Steinborn, M., Schmitz, C., Stäbler, A., Köhler, S., Veihelmann, A., et al. (2001). Extracorporeal shock-wave therapy for chronic lateral tennis elbowprediction of outcome by imaging. Arch. Orthop. Trauma Surg. 121, 379-384. doi: $10.1007 / \mathrm{s} 004020100261$

Mardani-Kivi, M., Karimi Mobarakeh, M., Hassanzadeh, Z., Mirbolook, A., Asadi, K., Ettehad, H., et al. (2015). Treatment outcomes of corticosteroid injection and extracorporeal shock wave therapy as two primary therapeutic methods for acute plantar fasciitis: a prospective randomized clinical trial. J. Foot Ankle Surg. 54, 1047-1052. doi: 10.1053/j.jfas.2015.04.026

Marmotti, A., Bonasia, D. E., Bruzzone, M., Rossi, R., Castoldi, F., Collo, G., et al. (2013). Human cartilage fragments in a composite scaffold for single-stage cartilage repair: an in vitro study of the chondrocyte migration and the influence of TGF-betal and G-CSF. Knee Surg. Sports Traumatol. Arthrosc. 21, 1819-1833. doi: 10.1007/s00167-0122244-7

Melegati, G., Tornese, D., Bandi, M., and Rubini, M. (2004). Comparison of two ultrasonographic localization techniques for the treatment of lateral epicondylitis with extracorporeal shock wave therapy: a randomized study. Clin. Rehabil. 18, 366-370. doi: 10.1191/0269215504cr762oa

Moretti, B., Garofalo, R., Genco, S., Patella, V., and Mouhsine, E. (2005). Mediumenergy shock wave therapy in the treatment of rotator cuff calcifying tendinitis. Knee Surg. Sports Traumatol. Arthrosc. 13, 405-410. doi: 10.1007/s00167-0050619-8

Murrell, G. A. (2007). Using nitric oxide to treat tendinopathy. Br. J. Sports Med. 41, 227-231. doi: 10.1136/bjsm.2006.034447

Notarnicola, A., Quagliarella, L., Sasanelli, N., Maccagnano, G., Fracella, M. R., Forcignanò, M. I., et al. (2014). Effects of extracorporeal shock wave therapy on functional and strength recovery of handgrip in patients affected by epicondylitis. Ultrasound Med. Biol. 40, 2830-2840. doi: 10.1016/j.ultrasmedbio.2014.07.010

Notarnicola, A., Tamma, R., Moretti, L., Fiore, A., Vicenti, G., Zallone, A., et al. (2012). Effects of radial shock waves therapy on osteoblasts activities. Musculoskelet. Surg. 96, 183-189. doi: 10.1007/s12306-012-0213-4
Ogden, J. A., Tóth-Kischkat, A., and Schultheiss, R. (2001). Principles of shock wave therapy. Clin. Orthop. Relat. Res. 387, 8-17. doi: 10.1097/00003086200106000-00003

Ongaro, A., Varani, K., Masieri, F. F., Pellati, A., Massari, L., Cadossi, R., et al. (2012). Electromagnetic fields (EMFs) and adenosine receptors modulate prostaglandin $\mathrm{E}(2)$ and cytokine release in human osteoarthritic synovial fibroblasts. J. Cell. Physiol. 227, 2461-2469. doi: 10.1002/jcp.22981

Osti, L., Buono, A. D., and Maffulli, N. (2015). Pulsed electromagnetic fields after rotator cuff repair: a randomized, controlled study. Orthopedics 38, e223-e228. doi: 10.3928/01477447-20150305-61

Pan, P. J., Chou, C. L., Chiou, H. J., Ma, H. L., Lee, H. C., and Chan, R. C. (2003). Extracorporeal shock wave therapy for chronic calcific tendinitis of the shoulders: a functional and sonographic study. Arch. Phys. Med. Rehabil. 84, 988-993. doi: 10.1016/S0003-9993(03)00010-8

Park, J. W., Yoon, K., Chun, K. S., Lee, J. Y., Park, H. J., Lee, S. Y., et al. (2014). Long-term outcome of low-energy extracorporeal shock wave therapy for plantar fasciitis: comparative analysis according to ultrasonographic findings. Ann. Rehabil. Med. 38, 534-540. doi: 10.5535/arm.2014.38.4.534

Peers, K. H., Lysens, R. J., Brys, P., and Bellemans, J. (2003). Cross-sectional outcome analysis of athletes with chronic patellar tendinopathy treated surgically and by extracorporeal shock wave therapy. Clin. J. Sport Med. 13, 79-83. doi: 10.1097/00042752-200303000-00003

Perlick, L., Luring, C., Bathis, H., Perlick, C., Kraft, C., and Diedrich, O. (2003). Efficacy of extracorporal shock-wave treatment for calcific tendinitis of the shoulder: experimental and clinical results. J. Orthop. Sci. 8, 777-783. doi: 10.1007/s00776-003-0720-0

Peters, J., Luboldt, W., Schwarz, W., Jacobi, V., Herzog, C., and Vogl, T. J. (2004). Extracorporeal shock wave therapy in calcific tendinitis of the shoulder. Skeletal Radiol. 33, 712-718. doi: 10.1007/s00256-004-0849-8

Radwan, Y. A., ElSobhi, G., Badawy, W. S., Reda, A., and Khalid, S. (2008). Resistant tennis elbow: shock-wave therapy versus percutaneous tenotomy. Int. Orthop. 32, 671-677. doi: 10.1007/s00264-007-0379-9

Rasmussen, S., Christensen, M., Mathiesen, I., and Simonson, O. (2008). Shockwave therapy for chronic Achilles tendinopathy: a double-blind, randomized clinical trial of efficacy. Acta Orthop. 79, 249-256. doi: $10.1080 / 17453670710015058$

Rebuzzi, E., Coletti, N., Schiavetti, S., and Giusto, F. (2008). Arthroscopy surgery versus shock wave therapy for chronic calcifying tendinitis of the shoulder. J. Orthop. Traumatol. 9, 179-185. doi: 10.1007/s10195-0080024-4

Riley, G. P., Curry, V., DeGroot, J., van El, B., Verzijl, N., Hazleman, B. L., et al. (2002). Matrix metalloproteinase activities and their relationship with collagen remodelling in tendon pathology. Matrix Biol. J. Int. Soc. Matrix Biol. 21, 185-195. doi: 10.1016/S0945-053X(01)00196-2

Rompe, J. D., Riedel, C., Betz, U., and Fink, C. (2001). Chronic lateral epicondylitis of the elbow: a prospective study of low-energy shockwave therapy and lowenergy shockwave therapy plus manual therapy of the cervical spine. Arch. Phys. Med. Rehabil. 82, 578-582. doi: 10.1053/apmr.2001.22337

Rubik, B. (1997). Bioelectromagnetics \& the future of medicine. Adm. Radiol. J. 16, 38-46.

Sabeti-Aschraf, M., Dorotka, R., Goll, A., and Trieb, K. (2005). Extracorporeal shock wave therapy in the treatment of calcific tendinitis of the rotator cuff. Am. J. Sports Med. 33, 1365-1368. doi: 10.1177/0363546504273052

Saxena, A., Ramdath, S. Jr., O'Halloran, P., Gerdesmeyer, L., and Gollwitzer, H. (2011). Extra-corporeal pulsed-activated therapy ("EPAT" sound wave) for Achilles tendinopathy: a prospective study. J. Foot Ankle Surg. 50, 315-319. doi: 10.1053/j.jfas.2011.01.003

Schmitt, J., Haake, M., Tosch, A., Hildebrand, R., Deike, B., and Griss, P. (2001). Low-energy extracorporeal shock-wave treatment (ESWT) for tendinitis of the supraspinatus. A prospective, randomised study. J. Bone Joint Surg. Br. 83, 873-876. doi: 10.1302/0301-620X.83B6.11591

Schofer, M. D., Hinrichs, F., Peterlein, C. D., Arendt, M., and Schmitt, J. (2009). High- versus low-energy extracorporeal shock wave therapy of rotator cuff tendinopathy: a prospective, randomised, controlled study. Acta Orthop. Belg. $75,452-458$.

Semenov, I., Xiao, S., and Pakhomov, A. G. (2013). Primary pathways of intracellular $\mathrm{Ca}(2+)$ mobilization by nanosecond pulsed electric field. Biochim. Biophys. Acta 1828, 981-989. doi: 10.1016/j.bbamem.2012.11.032 
Sharma, P., and Maffulli, N. (2005). Tendon injury and tendinopathy: healing and repair. J. Bone Joint Surg. Am. 87, 187-202. doi: 10.2106/JBJS.D.01850

Sharma, P., and Maffulli, N. (2006). Biology of tendon injury: healing, modeling and remodeling. J. Musculoskelet. Neuronal Interact. 6, 181-190.

Speed, C. A., Nichols, D., Richards, C., Humphreys, H., Wies, J. T., Burnet, S., et al. (2002b). Extracorporeal shock wave therapy for lateral epicondylitisa double blind randomised controlled trial. J. Orthop. Res. 20, 895-898. doi: 10.1016/S0736-0266(02)00013-X

Speed, C. A., Richards, C., Nichols, D., Burnet, S., Wies, J. T., Humphreys, H., et al. (2002a). Extracorporeal shock-wave therapy for tendonitis of the rotator cuff. A double-blind, randomised, controlled trial. J. Bone Joint Surg. Br. 84, 509-512. doi: 10.1302/0301-620X.84B4.12318

Staples, M. P., Forbes, A., Ptasznik, R., Gordon, J., and Buchbinder, R. (2008). A randomized controlled trial of extracorporeal shock wave therapy for lateral epicondylitis (tennis elbow). J. Rheumatol. 35, 2038-2046.

Stiller, M. J., Pak, G. H., Shupack, J. L., Thaler, S., Kenny, C., and Jondreau, L. (1992). A portable pulsed electromagnetic field (PEMF) device to enhance healing of recalcitrant venous ulcers: a double-blind, placebo-controlled clinical trial. Br. J. Dermatol. 127, 147-154. doi: 10.1111/j.1365-2133.1992.tb08047.x

Strauch, B., Patel, M. K., Rosen, D. J., Mahadevia, S., Brindzei, N., and Pilla, A. A. (2006). Pulsed magnetic field therapy increases tensile strength in a rat Achilles' tendon repair model. J. Hand Surg. Am. 31, 1131-1135. doi: 10.1016/j.jhsa.2006.03.024

Taunton, K. M. T. J., and Khan, K. M. (2003). Treatment of patellar tendinopathy with extracorporeal shock wave therapy. BC Med. J. 45, 500-507.

Tolstykh, G. P., Beier, H. T., Roth, C. C., Thompson, G. L., Payne, J. A., Kuipers, M. A., et al. (2013). Activation of intracellular phosphoinositide signaling after a single 600 nanosecond electric pulse. Bioelectrochemistry 94, 23-29. doi: 10.1016/j.bioelechem.2013.05.002

Trentini, R., Mangano, T., Repetto, I., Cerruti, P., Kuqi, E., Trompetto, C., et al. (2015). Short- to mid-term follow-up effectiveness of US-guided focal extracorporeal shock wave therapy in the treatment of elbow lateral epicondylitis. Musculoskelet. Surg. 99, 91-97. doi: 10.1007/s12306-015-0361-4

Trock, D. H. (2000). Electromagnetic fields and magnets. Investigational treatment for musculoskeletal disorders. Rheum. Dis. Clin. North Am. 26, 51-62. doi: 10.1016/S0889-857X(05)70119-8

Uzunca, K., Birtane, M., and Tastekin, N. (2007). Effectiveness of pulsed electromagnetic field therapy in lateral epicondylitis. Clin. Rheumatol. 26, 69-74. doi: 10.1007/s10067-006-0247-9

van der Worp, H., van den Akker-Scheek, I., van Schie, H., and Zwerver, J. (2013). ESWT for tendinopathy: technology and clinical implications. Knee Surg. Sports Traumatol. Arthrosc. 21, 1451-1458. doi: 10.1007/s00167-012-2009-3

van Leeuwen, M. T., Zwerver, J., and van den Akker-Scheek, I. (2009). Extracorporeal shockwave therapy for patellar tendinopathy: a review of the literature. Br. J. Sports Med. 43, 163-168. doi: 10.1136/bjsm.2008.050740

Varani, K., De Mattei, M., Vincenzi, F., Gessi, S., Merighi, S., Pellati, A., et al. (2008). Characterization of adenosine receptors in bovine chondrocytes and fibroblastlike synoviocytes exposed to low frequency low energy pulsed electromagnetic fields. Osteoarthr. Cartil. 16, 292-304. doi: 10.1016/j.joca.2007.07.004

Vetrano, M., d'Alessandro, F., Torrisi, M. R., Ferretti, A., Vulpiani, M. C., and Visco, V. (2011). Extracorporeal shock wave therapy promotes cell proliferation and collagen synthesis of primary cultured human tenocytes. Knee Surg. Sports Traumatol. Arthrosc. 19, 2159-2168. doi: 10.1007/s00167-011-1534-9

Vincenzi, F., Targa, M., Corciulo, C., Gessi, S., Merighi, S., Setti, S., et al. (2013). Pulsed electromagnetic fields increased the anti-inflammatory effect of $\mathrm{A}(2) \mathrm{A}$ and $\mathrm{A}(3)$ adenosine receptors in human T/C-28a2 chondrocytes and $\mathrm{hFOB} 1.19$ osteoblasts. PLoS ONE 8:e65561. doi: 10.1371/journal.pone.0065561
Visco, V., Vulpiani, M. C., Torrisi, M. R., Ferretti, A., Pavan, A., and Vetrano, M. (2014). Experimental studies on the biological effects of extracorporeal shock wave therapy on tendon models. A review of the literature. Muscles Ligaments Tendons J. 4, 357-361. doi: 10.11138/mlt $/ 2014.4 .3 .357$

Vulpiani, M. C., Trischitta, D., Trovato, P., Vetrano, M., and Ferretti, A. (2009). Extracorporeal shockwave therapy (ESWT) in Achilles tendinopathy. A longterm follow-up observational study. J. Sports Med. Phys. Fitness 49, 171-176.

Vulpiani, M. C., Vetrano, M., Savoia, V., Di Pangrazio, E., Trischitta, D., and Ferretti, A. (2007). Jumper's knee treatment with extracorporeal shock wave therapy: a long-term follow-up observational study. J. Sports Med. Phys. Fitness $47,323-328$.

Wang, C. J., Ko, J. Y., Chan, Y. S., Weng, L. H., and Hsu, S. L. (2007). Extracorporeal shockwave for chronic patellar tendinopathy. Am. J. Sports Med. 35, 972-978. doi: 10.1177/0363546506298109

Waugh, C. M., Morrissey, D., Jones, E., Riley, G. P., Langberg, H., and Screen, H. R. (2015). In vivo biological response to extracorporeal shockwave therapy in human tendinopathy. Eur. Cell. Mater. 29, 268-280. discussion: 80.

Wolf-Goldberg, T., Barbul, A., Ben-Dov, N., and Korenstein, R. (2013). Low electric fields induce ligand-independent activation of EGF receptor and ERK via electrochemical elevation of $\mathrm{H}(+)$ and ROS concentrations. Biochim. Biophys. Acta 1833, 1396-1408. doi: 10.1016/j.bbamcr.2013. 02.011

Yasuhara, R., Ohta, Y., Yuasa, T., Kondo, N., Hoang, T., Addya, S., et al. (2011). Roles of beta-catenin signaling in phenotypic expression and proliferation of articular cartilage superficial zone cells. Lab. Invest. 91, 1739-1752. doi: 10.1038/labinvest.2011.144

Yin, M. C., Ye, J., Yao, M., Cui, X. J., Xia, Y., Shen, Q. X., et al. (2014). Is extracorporeal shock wave therapy clinical efficacy for relief of chronic, recalcitrant plantar fasciitis? A systematic review and meta-analysis of randomized placebo or active-treatment controlled trials. Arch. Phys. Med. Rehabil. 95, 1585-1593. doi: 10.1016/j.apmr.2014.01.033

Zhang, Y. E. (2011). A special issue on TGF-beta signaling and biology. Cell Biosci. 1:39. doi: 10.1186/2045-3701-1-39

Zhou, J., Li, X., Liao, Y., Feng, W., Fu, C., and Guo, X. (2015). Pulsed electromagnetic fields inhibit bone loss in streptozotocin-induced diabetic rats. Endocrine 49, 258-266. doi: 10.1007/s12020-014-0439-z

Zwerver, J., Dekker, F., and Pepping, G. J. (2010). Patient guided Piezo-electric Extracorporeal Shockwave Therapy as treatment for chronic severe patellar tendinopathy: a pilot study. J. Back Musculoskelet. Rehabil. 23, 111-115. doi: 10.3233/BMR-2010-0257

Zwerver, J., Hartgens, F., Verhagen, E., van der Worp, H., van den AkkerScheek, I., and Diercks, R. L. (2011). No effect of extracorporeal shockwave therapy on patellar tendinopathy in jumping athletes during the competitive season: a randomized clinical trial. Am. J. Sports Med. 39, 1191-1199. doi: $10.1177 / 0363546510395492$

Conflict of Interest Statement: The authors declare that the research was conducted in the absence of any commercial or financial relationships that could be construed as a potential conflict of interest.

Copyright $\odot 2015$ Rosso, Bonasia, Marmotti, Cottino and Rossi. This is an openaccess article distributed under the terms of the Creative Commons Attribution License (CC BY). The use, distribution or reproduction in other forums is permitted, provided the original author(s) or licensor are credited and that the original publication in this journal is cited, in accordance with accepted academic practice. No use, distribution or reproduction is permitted which does not comply with these terms. 